\title{
MODIS observed increase in duration and spatial extent of sediment plumes in Greenland fjords
}

\author{
B. Hudson ${ }^{1,2}$, I. Overeem ${ }^{2}$, D. McGrath ${ }^{3}$, J. P. M. Syvitski ${ }^{1,2}$, A. Mikkelsen ${ }^{4}$, and B. Hasholt ${ }^{4}$ \\ ${ }^{1}$ University of Colorado, Department of Geological Sciences, Boulder, CO, USA \\ ${ }^{2}$ University of Colorado, Community Surface Dynamics Modeling System, INSTAAR, Boulder, CO, USA \\ ${ }^{3}$ University of Colorado, CIRES, Boulder, CO, USA \\ ${ }^{4}$ University of Copenhagen, Copenhagen, Denmark \\ Correspondence to: B. Hudson (benjamin.hudson@ colorado.edu)
}

Received: 7 November 2013 - Published in The Cryosphere Discuss.: 20 December 2013

Revised: 9 May 2014 - Accepted: 24 May 2014 - Published: 4 July 2014

\begin{abstract}
The freshwater flux from the Greenland Ice Sheet (GrIS) to the North Atlantic Ocean carries extensive but poorly documented volumes of sediment. We develop a suspended sediment concentration (SSC) retrieval algorithm using a large Greenland specific in situ data set. This algorithm is applied to all cloud-free NASA Moderate Resolution Imaging Spectrometer (MODIS) Terra images from 2000 to 2012 to monitor SSC dynamics at six river plumes in three fjords in southwest Greenland. Melt-season mean plume SSC increased at all but one site, although these trends were primarily not statistically significant. Zones of sediment concentration $>50 \mathrm{mg} \mathrm{L}^{-1}$ expanded in three river plumes, with potential consequences for biological productivity. The high SSC cores of sediment plumes $\left(>250 \mathrm{mg} \mathrm{L}^{-1}\right)$ expanded in one-third of study locations. At a regional scale, higher volumes of runoff were associated with higher meltseason mean plume SSC values, but this relationship did not hold for individual rivers. High spatial variability between proximal plumes highlights the complex processes operating in Greenland's glacio-fluvial-fjord systems.
\end{abstract}

\section{Introduction}

The Greenland Ice Sheet (GrIS) is the largest ice mass in the Northern Hemisphere, containing the equivalent of $7 \mathrm{~m}$ of global sea level (Bamber et al., 2013). High rates of seasonal mass turnover, coupled with decadal-scale ice sheet mass imbalances (142 $\pm 49 \mathrm{Gt} \mathrm{yr}^{-1}$ between 1992 and 2011), result in hydrologic fluxes from the GrIS exceeding $300 \mathrm{~km}^{3} \mathrm{yr}^{-1}$ (Hanna et al., 2008; Shepherd et al., 2012).
Mass loss from the GrIS primarily occurs through iceberg calving and meltwater runoff. These losses occur at two distinct types of outlets: (1) approximately two-thirds of mass loss occurs at marine terminating outlets where both processes operate, and (2) one-third of mass loss occurs via meltwater runoff at land terminating outlets (Bamber et al., 2012). This paper focuses on rivers draining the landterminating ice sheet margin. Total ice sheet imbalance has increased four-fold over the past two decades, increasing from $51 \pm 65 \mathrm{Gt} \mathrm{yr}^{-1}$ in the 1990 s to $211 \pm 37 \mathrm{Gt} \mathrm{yr}^{-1}$ between 2000 to 2011 (Shepherd et al., 2012). This imbalance is the result, in part, of an increase in the ablation area of the GrIS (McGrath et al., 2013) and increased rates of meltwater production (Ettema et al., 2009).

Runoff exits the ice sheet at more than 400 distinct outlets (Lewis and Smith, 2009) and typically contains large volumes of sediment produced beneath the ice sheet. Sediment is produced through two key mechanisms beneath temperate based glaciers: first, subglacial water pressure can create and/or exploit cracks in bedrock that allow ice to quarry and remove it and second, rocks embedded in basal ice (e.g., those quarried) abrade bedrock over which it flows (Anderson and Anderson, 2010). These processes are both partially controlled by the presence and volume of water, which varies on temporal scales of hours to months (McGrath et al., 2011). For instance, variations in surface melt entering the ice sheet can modulate the effective pressure at the ice sheet's bed, thus enhancing quarrying and can also modify the basal sliding velocity, which in turn can increase abrasion (Anderson and Anderson, 2010; Zwally et al., 2002). 


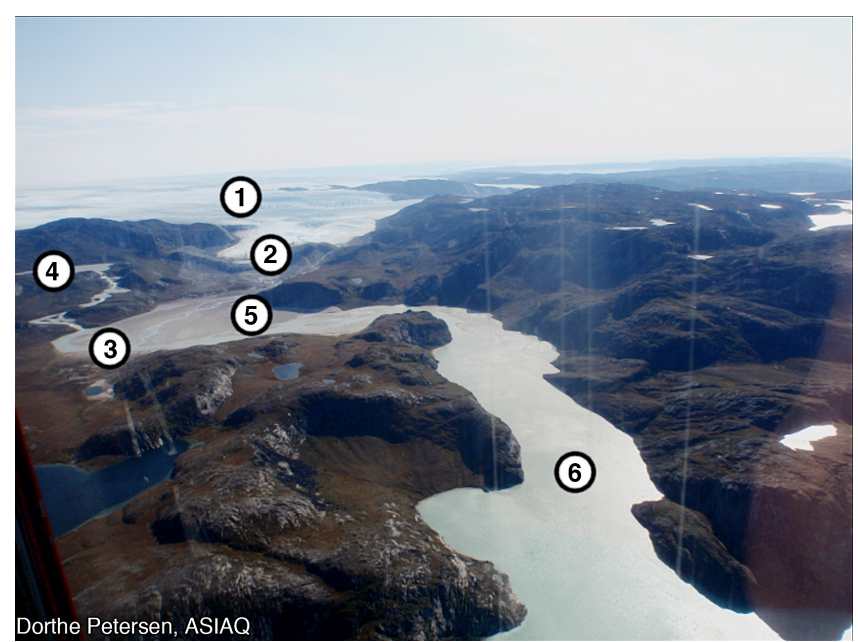

Figure 1. Conceptual diagram of processes that influence delivery of sediment from ice sheet to fjord, plotted on top of aerial photograph of the Pakitsuup south river and Pakitsuup fjord. Sediment produced subglacially may be stored until removed by water or ice (1). Once exported by the glacier (2), sediment can be transported by rivers (3). While transported by the river, it can potentially be stored or passed through lakes (4), stored on the river's outwash plain (5) until it is discharged into the ocean (6). Sediment stored on the river's outwash plain may be remobilized at a later time by the river (5). Additional sediment can be sourced locally from the landscape, for example through bank erosion. Photograph courtesy of Dorthe Petersen, ASIAQ.

A complex and highly variable relationship exists between the glacier hydrologic network and the transport of sediment (Fenn et al., 1985; O'Farrell et al., 2009; Østrem, 1975). Spatio-temporal variability in sub-glacial hydrologic networks can drive variability of sediment emerging from glaciers (Collins, 1990) and transient flushes of sediment from glaciers in Greenland have been observed (Stott and Grove, 2001). Water accessing areas of the bed not previously reached may cause increases in SSC per unit discharge (Alley et al., 1997). On the other hand, areas of the bed that the sub-glacial hydrologic network often reaches may be depleted in sediment (Alley et al., 1997).

Once water and sediment exit the glacier's hydrologic system and enters a river, fluvial processes control its transport. As Fig. 1 illustrates, sediment produced subglacially may be stored until removed by water or ice (1). Once exported by the glacier (2), sediment can be transported by rivers (3). While transported by the river, it can potentially be stored or passed through lakes (4), stored on the river's outwash plain (5) until it is discharged into the ocean (6). Sediment stored on the river's outwash plain may be remobilized at a later time by the river (5). Additional sediment can be sourced locally from the landscape, for example through bank erosion, but this is not treated explicitly here (Mernild and Hasholt, 2009).
Upon entry into the ocean, river water decelerates rapidly and entrained sediment settles. In the ocean sediment travels as a function of the velocity of the water that moves it away from the river mouth and the rate it sinks from the surface layer (and satellite's view). Initially, the rivers velocity at its mouth $\left(u_{0}\right)$ sets down fjord velocity (Syvitski, 1990). The extent of fluvial control typically ends $\sim 5.2$ river widths seaward of its mouth (Albertson et al., 1950). Beyond this point, the fjord's estuarine circulation conveys the sediment seaward (Inall and Gillibrand, 2010). Sediment settling velocity (removal rate) is a function of its grain size, density, and biological process such as flocculation that alter the particle's characteristics (Syvitski and Murray, 1981). A sediment plume's centerline SSC can be written as a function of distance from river mouth $(x)$ as (modified from Syvitski et al., 1988)

$\operatorname{SSC}(x)=\operatorname{SSC}_{0} \times \exp \left(-\left(\frac{u_{0}}{\lambda}\right) \times x\right)$,

where $\mathrm{SSC}_{0}$ is the SSC of the river as it enters a fjord and $\lambda$ is the size dependent particle removal rate constant (Peckham, 2008; Syvitski et al., 1985).

A number of additional processes operating in the fjord environment can influence sediment plume dynamics. The large-scale Coriolis effect can deflect the plume, although this is dependent on river mouth geometry, fjord width, and water column stratification in the fjord (Cushman-Rosin et al., 1994). Wind can cause vertical mixing of the water column in sea-ice free conditions (Cottier et al., 2010). Often the topography of the fjord helps steer winds up or down fjord. During summer, sea breezes caused by differential heating of the land and water surface can cause strong up fjord winds. In winter, strong katabatic winds can cause strong down fjord winds (Seidenkrantz et al., 2007). This bi-modal wind flow can help aid or retard estuarine circulation and cause localized upwelling (Skogseth et al., 2007).

The relationship between water discharge and river SSC is largely unstudied in Greenlandic rivers, although a power law relationship often exists between a river's SSC and its discharge, $Q$ : river SSC $=a Q^{b}$ (Morehead et al., 2003; Syvitski et al., 2000), where $a$ and $b$ are rating parameters. This relationship is often valid for braided rivers with glacierized catchments. Church (1972) found this relationship for the braided Lewis River (90\% glacierized catchment including the Barnes ice cap) and the upper south river, Ekalugad fjord (50\% glacierized catchment on Baffin Island). Two examples from Greenland support this simple relationship. First, in situ observations on the Watson River show increased sediment load during high discharge years (Hasholt et al., 2013) and second, Chu et al. (2012) found that Polar MM5 modeled positive degree-days, a proxy for meltwater production, was the most significant driver of regional fjord SSC variability.

While Greenland fjord SSC is understudied it offers the potential to be an important indicator of environmental change and is relevant to subglacial sediment dynamics and 
coastal biological productivity. Sediment delivers essential nutrients to the coastal ocean (Statham et al., 2008), although high levels of suspended sediment also reduces the availability of light (Retamal et al., 2008). Sediment may impact biological productivity, such as pelagic zooplankton feeding efficiency and production rates (Arendt et al., 2011).

Widespread in situ observations of river and fjord SSC in Greenland are logistically infeasible; in fact Hasholt (1996) and Hasholt et al. (2006) identified $<15$ locations where river sediment dynamics had been studied, even for a short period of time. Instead, recent efforts have focused on using orbital remote sensing to monitor fjord sediment dynamics (Chu et al., 2009, 2012; McGrath et al., 2010; Tedstone and Arnold, 2012).

Here, we build on previous efforts using orbital remote sensing to monitor fjord sediment dynamics along the coast of the GrIS (Chu et al., 2009, 2012; McGrath et al., 2010; Tedstone and Arnold, 2012). We develop an improved SSC retrieval algorithm based on a robust set of in situ SSC observations. This algorithm is applied to the entire 13 year cloud-free MODIS visible satellite imagery record at three sites along the western margin of the GrIS to better characterize SSC variability at these sites. Further, we explore the complex relationship between fjord SSC and GrIS runoff and test the hypothesis that increased freshwater discharge due to increased ice sheet melt has elevated melt-season SSC.

\section{Study areas}

Our study sites consist of three fjords in southwest Greenland (Pakitsuup, Kangerlussuaq, and Ameralik), fed by six proglacial river systems (Fig. 2). GrIS catchment areas (Fig. 3) were calculated from the local hydrostatic pressure field of the ice sheet, which combines surface elevation data with basal topography (Lewis and Smith, 2009; Cuffey and Patterson, 2010). Surface elevations are from the Greenland Mapping Project (GIMP) digital elevation model (30 m posting, Howat et al., 2014). Bedrock topography of the Pakitsuup region is from the $500 \mathrm{~m}$ resolution University of Kansas Center for the Remote Sensing of Ice Sheets (CRESIS) Jacobshavn basal topography data set (https://data.cresis.ku.edu/data/grids/). For the Kangerlussuaq and Ameralik regions a coarser $5 \mathrm{~km}$ resolution basal topography from Bamber et al. (2001) was used. Flow routing and catchment delineation was performed following a D-infinity approach using RiverTools 3.0 (Peckham, 2009). Catchment areas describe only the portion of the watershed covered by glacial ice, as these areas are the primary sources of water and sediment to the systems studied.

\subsection{Pakitsuup fjord}

Pakitsuup fjord (also spelled Pakitsoq) is located near the town of Ilulissat and receives melt from two small
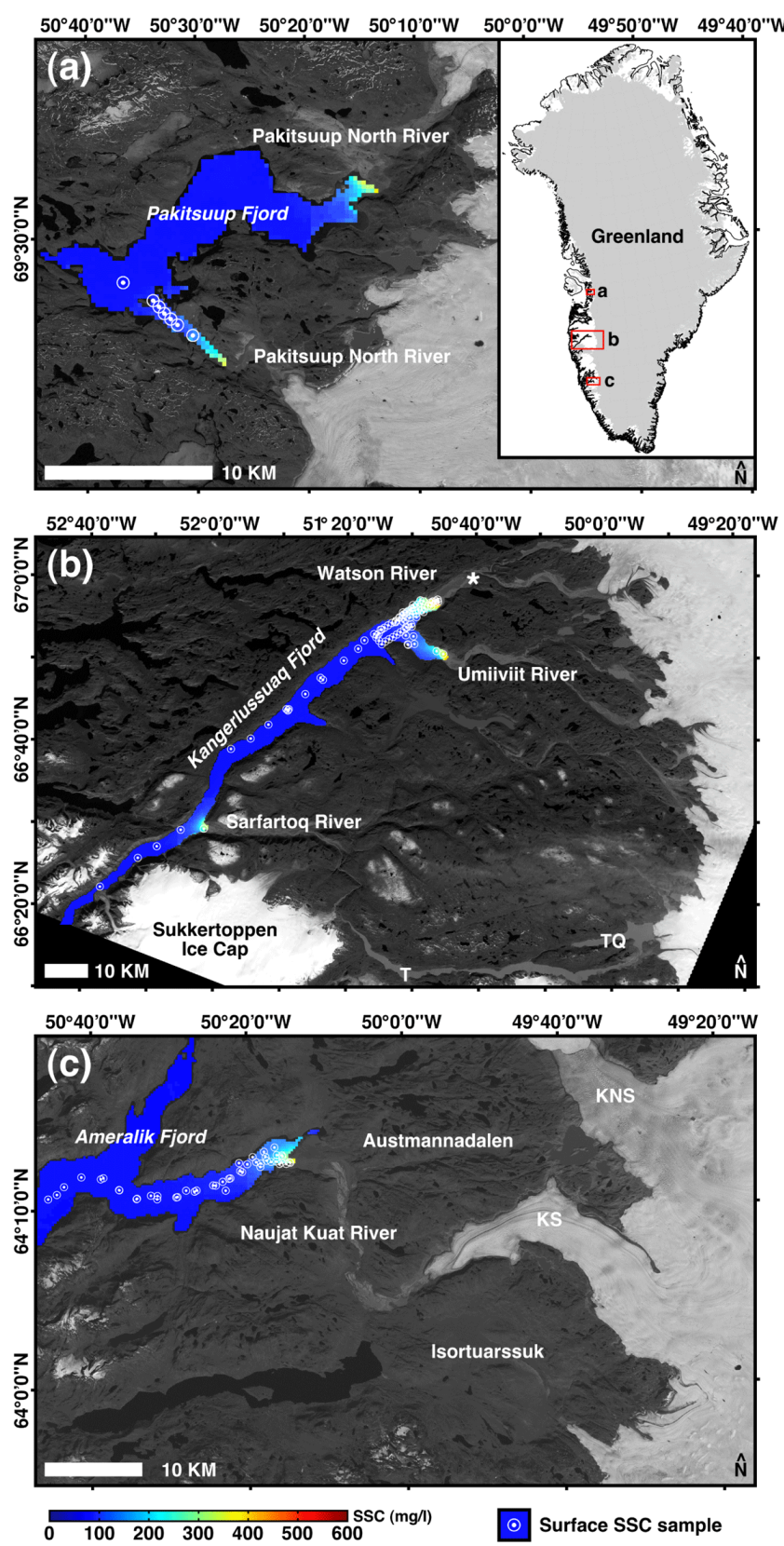

Figure 2. Overview map of study fjords, with surface suspended sediment concentration (SSC) sample locations used in retrieval overlaid on 13 year mean SSC values derived from MODIS algorithm. Background images are Landsat 7 ETM+ from (a) 7 July 2001, (b) 20 August 2002, and (c) 3 August 2001. Inset shows location of fjords relative to Greenland Ice Sheet. An asterisk shows the location of the Watson River gauge.

river systems. The Pakitsuup north river $\left(69^{\circ} 31^{\prime} 45.5^{\prime \prime} \mathrm{N}\right.$, $50^{\circ} 13^{\prime} 23.7^{\prime \prime} \mathrm{W}$ ) has two branches, respectively, 8 and $10 \mathrm{~km}$ long. As Fig. 3a shows, it drains a catchment of the GrIS $\sim 302 \mathrm{~km}^{2}$ (Table 1), which reaches a maximum height of $\sim 1169$ meters above sea level (m a.s.1.). The Pakitsuup south river $\left(69^{\circ} 26^{\prime} 5.9^{\prime \prime} \mathrm{N}, 50^{\circ} 27^{\prime} 53.3^{\prime \prime} \mathrm{W}\right)$ flows $7 \mathrm{~km}$ from the 


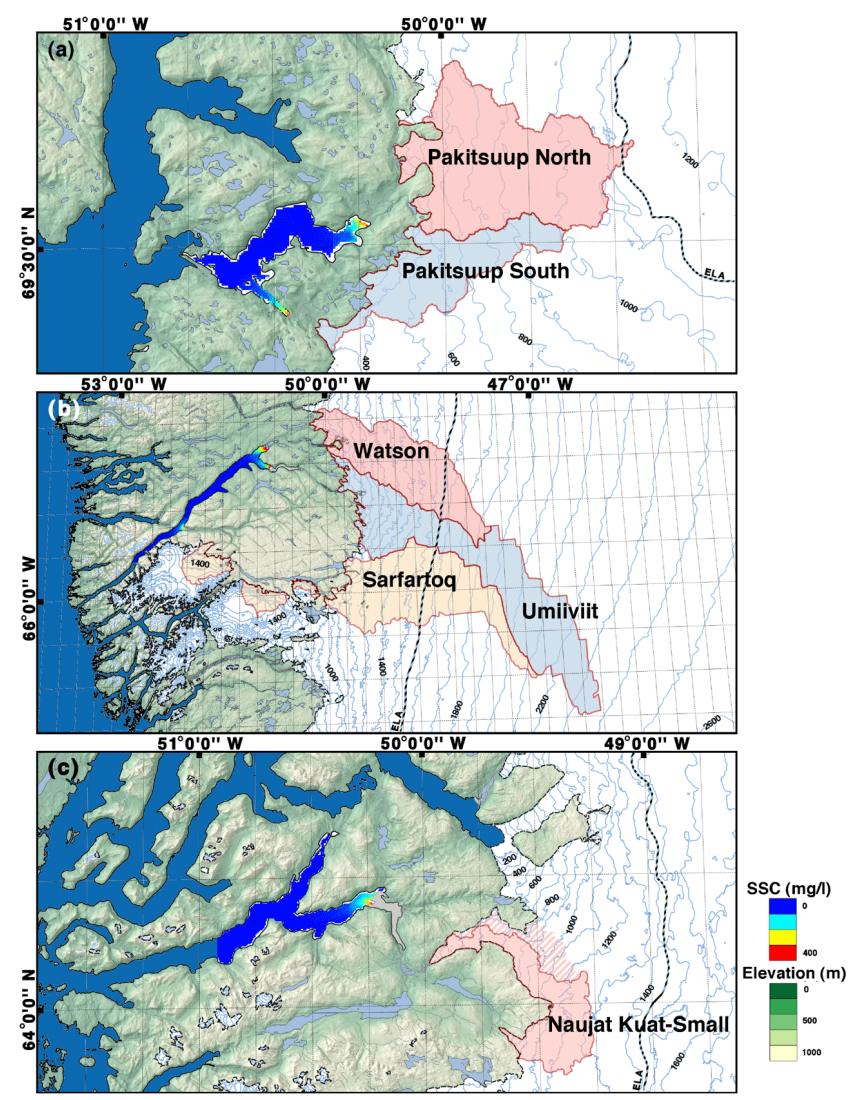

Figure 3. Land surface digital elevation model (DEM), ice sheet topographic contours, and glacier catchment area for rivers and fjords discussed in paper. Land DEM and ice sheet contours were derived from the GIMP DEM. Equilibrium line altitudes (ELA) discussed in Sect. 2 also plotted on ice sheet for reference, as are 13 year mean SSC concentration. For (c), Naujat Kuat-Small is delineated with sold pink color. The entire Naujat Kuat catchment combines both solid and diagonal striped pink regions. Latitude and longitude grid is in 0.25 decimal degree intervals.

margin of the GrIS that feeds it along its southern tributary. A northern tributary flows $20 \mathrm{~km}$ through a series of lakes, before combining with the southern tributary approximately $4 \mathrm{~km}$ from the river mouth. It is the smallest catchment studied $\left(\sim 143 \mathrm{~km}^{2}\right)$ with the lowest maximum elevation ( $\sim 1020$ m a.s.l.). Mernild et al. (2010) estimate that the equilibrium line altitude (ELA) for the region is approximately $1125 \mathrm{~m}$ a.s.l. (Fig. 3a).

\subsection{Kangerlussuaq fjord}

Three major river systems discharge water and sediment into Kangerlussuaq fjord (Søndre Strømfjord). The Watson River $\left(66^{\circ} 57^{\prime} 53.7^{\prime \prime} \mathrm{N}, 50^{\circ} 51^{\prime} 49.8^{\prime \prime} \mathrm{W}\right)$ enters at the northeast head of Kangerlussuaq fjord. A discharge gauging station has operated on the river since 2007 at the town of Kangerlussuaq (asterisk on Fig. 2b), $10 \mathrm{~km}$ from the river mouth (Hasholt et al., 2013). The Watson River receives water from two tributaries, each $\sim 34 \mathrm{~km}$ in length and has a combined GrIS catchment area of $3639 \mathrm{~km}^{2}$, (Fig. 3b). This is smaller than previously published values (e.g., Hasholt et al., 2013) where the catchment area is based on the surface topography. This catchment has a maximum elevation of $1860 \mathrm{~m}$ a.s.l. (Table 1) and a mean ELA of $\sim 1550 \mathrm{~m}$ a.s.l. (van de Wal et al., 2012).

The Umiiviit River ( $\left.66^{\circ} 50^{\prime} 01.6^{\prime \prime} \mathrm{N}, 50^{\circ} 48^{\prime} 37.3^{\prime \prime} \mathrm{W}\right)$ flows into the southeastern head of Kangerlussuaq fjord and drains a catchment area of $6320 \mathrm{~km}^{2}$ with a maximum elevation of $\sim 2390 \mathrm{~m}$ a.s.l. In comparison, the Umiiviit River is $>85 \mathrm{~km}$ in length, more than double that of the Watson River branches.

The Sarfartoq River $\left(66^{\circ} 29^{\prime} 29.6^{\prime \prime} \mathrm{N}, 52^{\circ} 01^{\prime} 29.5^{\prime \prime} \mathrm{W}\right)$ discharges into Kangerlussuaq fjord $\sim 79 \mathrm{~km}$ down fjord from the northeast fjordhead. From its mouth, the river stretches $53 \mathrm{~km}$ in a narrow valley to a lake, Tasersiaq (T on Fig. $2 \mathrm{~b}$ ). Tasersiaq is $\sim 71 \mathrm{~km}$ long and $14 \mathrm{~m}$ deep (Goldthwait et al., 1964), and bordered by the Sukkertoppen ice cap, lobes of the GrIS, and an $18 \mathrm{~km}$ long lake, Tasersiaq Qalia (TQ on Fig. 2b). The Sarfartoq River has $5385 \mathrm{~km}^{2}$ of glaciated catchment with a maximum height of $2157 \mathrm{~m}$ a.s.l. Approximately $919 \mathrm{~km}^{2}$ of this area is covered by minor ice caps and glaciers not part of the GrIS (e.g., the Sukkertoppen ice cap). It is the only river in the study that receives melt from both peripheral glaciers and the GrIS.

\subsection{Ameralik fjord}

Ameralik fjord (also known as Lysefjord, or Ameralgda fjord if considering only the innermost part of the fjord) is located close to Greenland's capitol city, Nuuk. The Naujat Kuat River $\left(64^{\circ} 12^{\prime} 37.5^{\prime \prime} \mathrm{N}, 50^{\circ} 12^{\prime} 31.0^{\prime \prime} \mathrm{W}\right)$ flows $26 \mathrm{~km}$ from the margin of the GrIS, receiving melt from a catchment $460 \mathrm{~km}^{2}$, with a maximum height of $1342 \mathrm{ma}$ a.s.l. Mote (2000) estimated the regional ELA near $1450 \mathrm{~m}$ a.s.l. Meltwater discharge originates from two lobes of the GrIS. The southern lobe discharges water into an $8 \mathrm{~km}$ long lake, Isortuarssuk (Fig. 2), a short distance from its terminus. The northern lobe, Kangaussarssup Sermia (KS on Fig. 2), discharges water to the river uninterrupted by lakes. On the north side of Kangaussarssup Sermia ice margin lakes exist. These lakes historically drained down a valley (the Austmannadalen) to a point $\sim 7 \mathrm{~km}$ from the river mouth. Since 2004, the lakes drain north into Kangiata Nunaata Sermia (KNS on Fig. 2c, Weidick and Citterio, 2011). As the MODIS record straddles this drainage realignment, Fig. $3 \mathrm{c}$ and Table 1 provide two delineations, one with the lakes (Naujat Kuat) and one without (Naujat Kuat-Small). At its smallest, the on-ice catchment area is $356 \mathrm{~km}^{2}$, at largest it is $\sim 460 \mathrm{~km}^{2}$. This uncertainty in drainage basin delineation does not affect the maximum elevation of the drainage or the general shape of the hypsometric curve. Unless otherwise noted, the Naujat Kuat-Small catchment was used in subsequent analysis. 
Table 1. Various measures of glacier catchments in paper.

\begin{tabular}{lrrrrrr}
\hline Catchment & $\begin{array}{r}\text { Maximum } \\
\text { elevation }(\mathrm{m})\end{array}$ & $\begin{array}{r}\text { Minimum } \\
\text { elevation }(\mathrm{m})\end{array}$ & $\begin{array}{r}\text { Area } \\
\left(\mathrm{km}^{2}\right)\end{array}$ & $\begin{array}{r}\text { Area under } \\
\text { ELA }\left(\mathrm{km}^{2}\right)\end{array}$ & $\begin{array}{r}\text { Area under } \\
\text { ELA (\%) }\end{array}$ & $\begin{array}{r}\text { Area-weighted } \\
\text { average elevation }(\mathrm{m})\end{array}$ \\
\hline Pakitsuup north & 1169 & 98 & 302 & 300 & 99.3 & 852 \\
Pakitsuup South & 1020 & 84 & 143 & 143 & 100 & 610 \\
Watson & 1860 & 106 & 3640 & 2864 & 79 & 1248 \\
Umiiviit & 2387 & 257 & 6320 & 2072 & 33 & 1734 \\
Sarfartoq & 2157 & 671 & 5385 & 3291 & 61 & 1503 \\
Sarfartoq - GrIS only & 2157 & 728 & 4466 & 2616 & 59 & 1529 \\
Naujat Kuat & 1342 & 228 & 460 & 460 & 100 & 1032 \\
Naujat Kuat-Small & 1342 & 185 & 356 & 356 & 100 & 1049 \\
\hline
\end{tabular}

\section{Methods}

\subsection{Suspended sediment samples}

We collected surface water samples as part of oceanographic surveys during the 2008, 2010, 2011, and 2012 summer seasons (Table 2). In total, 140 samples, covering 12 days in all major melt months were used to develop the SSC retrieval algorithm. Three additional water samples were collected from Orpigsoq fjord $\left(68^{\circ} 38^{\prime} 30.9^{\prime \prime} \mathrm{N}, 50^{\circ} 54^{\prime} 45.5^{\prime \prime} \mathrm{W}\right)$ on 2 July 2011 which are used in algorithm development, although this fjord was not included in the present study.

Surface water samples were collected along variably spaced transects in each fjord (Fig. 2) by dipping a $1000 \mathrm{~mL}$ bottle into the near-surface layer while a handheld GPS noted the geographic location. Samples were then vacuum filtered through pre-weighed Whatman GF/F filters, rinsed with distilled water to remove salt, freeze dried, and reweighed to determine SSC. Fjord SSC ranged between 1.2 and $716 \mathrm{mg} \mathrm{L}^{-1}$ with a mean SSC of $73 \mathrm{mg} \mathrm{L}^{-1}$. One sample collected from the shallow river mouth of the Watson river on 9 July 2011 had an SSC of $1581 \mathrm{mg} \mathrm{L}^{-1}$ but was excluded from analysis because it could not be determined if the sampling boat had disturbed bottom sediments.

\subsection{SSC retrieval algorithm based on MODIS reflectance}

MODIS Terra MOD02 $250 \mathrm{~m}$ imagery and the MOD03 geolocation data product for each swath image were downloaded using NASA's Reverb Earth Science Data Discovery Tool (http://reverb.echo.nasa.gov/reverb/). Image processing was completed using Exelis ENVI 4.8 software, including the MODIS Conversion Toolkit (http://www.exelisvis.com) and included georeferencing, a bow tie correction, and an atmospheric correction using dark object subtraction. The latter is completed using a cloud-free open ocean pixel from each scene (Kirk, 2011; Miller and McKee, 2004). Georeferenced images were compared against the Danish National Survey and Cadastre (DNSC) Greenland coastline vector file and were manually adjusted to agree with the DNSC coastline if a discrepancy existed.

SSC values were compared to co-located band one (620 to $670 \mathrm{~nm}$ ) and two ( 841 to $876 \mathrm{~nm}$ ) reflectance values. Barbieri et al. (1997) defined the MOD02 reflectance data product as the bidirectional reflectance factor of the Earth $\left(\rho_{\mathrm{ev}}\right)$ multiplied by cosine of the solar zenith angle at the earth scene $\left(\theta_{\mathrm{ev}}\right)$

$\rho_{\mathrm{ev}} \times \cos \theta_{\mathrm{ev}}$.

With $\rho_{\text {ev }}$ defined as

$\rho_{\mathrm{ev}}=\frac{L_{\mathrm{ev}}}{E_{\mathrm{i}} \cos \theta_{\mathrm{ev}}}$,

where $L_{\mathrm{ev}}$ is the earth view spectral radiance $\left(\mathrm{W} \mathrm{m}^{-2} \mathrm{sr}^{-1} \mathrm{~nm}^{-1}\right), \quad$ and $E_{\mathrm{i}}$ is solar irradiance $\left(\mathrm{W} \mathrm{m}^{-2} \mathrm{~nm}^{-1}\right.$ ). Combing these two equations, reflectance is calculated as

$R_{\mathrm{rs}}=\frac{L_{\mathrm{ev}}}{E_{\mathrm{i}}}$.

Ocean color remote-sensing literature often define $R_{\mathrm{rs}}$ as radiance reflectance (Kirk, 2011) or remote-sensing reflectance (Mobley, 1999), though technically $E_{\mathrm{i}}$ should be downwelling irradiance directly above the surface of the water $\left(E_{\mathrm{d}}\right)$, not from the top of atmosphere $\left(E_{\mathrm{i}}\right)$. Despite this difference, we use the $R_{\mathrm{rs}}$ notation. Following Miller and McKee (2004), variations in scene solar zenith angle were corrected on an individual pixel basis to arrive at

$R_{\mathrm{rsc}}=R_{\mathrm{rs}} \times \frac{1}{\cos \theta_{\mathrm{ev}}}$.

We developed a fjord SSC retrieval algorithm using both MODIS band one and two and the co-located in situ sediment samples (locations shown on Fig. 2; relationship between variables on Fig. 4). Unlike previous SSC algorithms developed using MODIS imagery for Greenland, which became saturated above $80 \mathrm{mg} \mathrm{L}^{-1}$ (e.g., Chu et al., 2009), the addition of band two, which measures reflectance in the near 
Table 2. Surface water samples used in retrival algorithm.

\begin{tabular}{lllr}
\hline $\begin{array}{l}\text { River } \\
\text { plume }\end{array}$ & $\begin{array}{l}\text { Coordinates of } \\
\text { river mouth }\end{array}$ & $\begin{array}{l}\text { Dates samples } \\
\text { collected }\end{array}$ & $\begin{array}{r}\text { Number of } \\
\text { samples used }\end{array}$ \\
\hline $\begin{array}{l}\text { Pakitsuup South } \\
\text { Orpigsoq fjord }\end{array}$ & $69^{\circ} 26^{\prime} 5.93^{\prime \prime} \mathrm{N}, 50^{\circ} 27^{\prime} 53.35^{\prime \prime} \mathrm{W}$ & 14 July 2011 & 7 \\
Watson & $66^{\circ} 57^{\prime} 53.7^{\prime \prime} \mathrm{N}, 50^{\circ} 51^{\prime} 49.8^{\prime \prime} \mathrm{W}$ & $\begin{array}{l}\text { 2 July 2011 } \\
\text { 4 June 2008, 16 June 2010, 9 July 2011, 19 July }\end{array}$ & 3 \\
& & 2012, 21 July 2012, 23 July 2012, 24 July 2012 & 74 \\
Umiiviit & $66^{\circ} 50^{\prime} 01.6^{\prime \prime} \mathrm{N}, 50^{\circ} 48^{\prime} 37.3^{\prime \prime} \mathrm{W}$ & 23 July 2012 & 7 \\
Sarfartoq & $66^{\circ} 29^{\prime} 29.6^{\prime \prime} \mathrm{N}, 52^{\circ} 01^{\prime} 29.5^{\prime \prime} \mathrm{W}$ & 24 July 2012 & 5 \\
Naujat Kuat & $64^{\circ} 12^{\prime} 37.5^{\prime \prime} \mathrm{N}, 50^{\circ} 12^{\prime} 31.0^{\prime \prime} \mathrm{W}$ & 30 June 2011, 15 August 2012, 16 August 2012 & 47 \\
\hline
\end{tabular}

infrared, allows the algorithm to be sensitive to higher SSC. The final retrieval algorithm was

$\mathrm{SSC}=1.80 \times \exp \left(19.11 \times\left(R_{\mathrm{rsc}, \mathrm{B} 1}+R_{\mathrm{rsc}, \mathrm{B} 2}\right)\right)$.

The in situ SSC data set included samples from fjords with variable salinity. Using a Seabird 19 conductivity, temperature, and depth probe, we measured salinities as high as 25 PSU (Ameralik fjord) and as low as 1 PSU (Kangerlussuaq fjord) in the top meter of the surface layer coincident with surface water sample collection locations. The variable salinity during our oceanographic surveys, and the independence of Eq. (6) on this parameter, suggests that this retrieval technique can be applied to disparate locations with variable oceanographic properties.

Following algorithm development, we processed $\sim 300$ sea ice free swath scenes per year (spanning day of the year 135 to 295) to map fjord SSC values over the entire melt season. Appendix A describes the full processing details.

\subsection{Error from sampling irregularities caused by clouds}

Since the year 2000, MODIS Terra satellite observations have provided an ongoing daily record in this region, although, as common in polar regions, the presence of clouds compromise the imagery's utility as an observational tool. In total, clear-sky conditions existed for between 5 and $21 \%$ of all available fjord pixels during a given summer season.

Computational experiments following Gregg and Casey (2007) were used to assess this potential sampling bias. A simulated data set based on the entire 13 year data record was created and then masked with MODIS observed cloud cover to understand how cloud obscuration impacted SSC statistics.

To create the simulated data set, we calculated a 13 year mean SSC map on a pixel-by-pixel basis as

$\overline{13 \text { year SSC }}=\frac{\sum_{\text {year }=2000}^{2012} \sum_{\text {day }=135}^{295} \mathrm{SSC}_{i, j}}{\sum_{\text {year }=2000}^{2012} N_{i, j}}$,

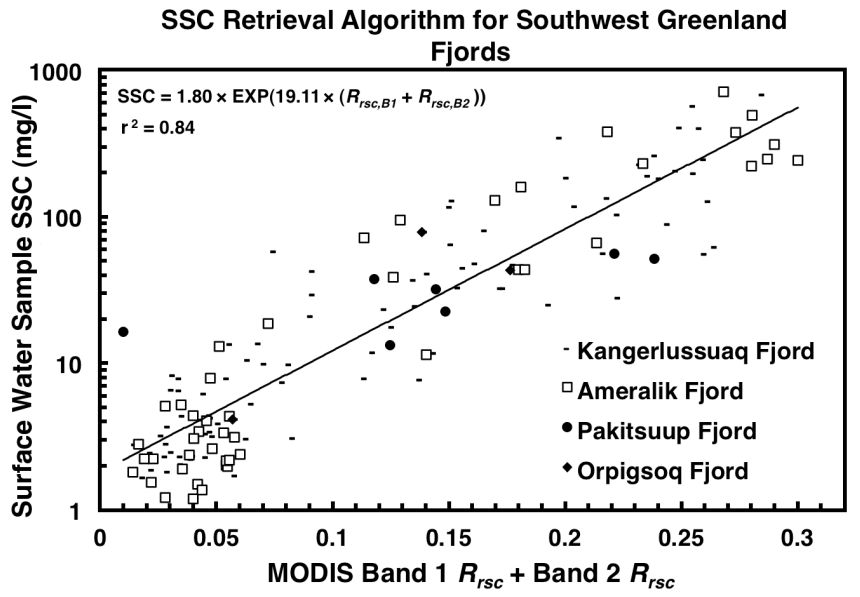

Figure 4. Relationship between MODIS band one and two corrected remote-sensing reflectance $\left(R_{\mathrm{rsc}}\right)$ and surface water sample $\mathrm{SSC}$ values used in retrieval algorithm.

where $N$ was the number of times the pixel passed all tests and was used in the analysis, $i$ is pixel location in the horizontal direction and $j$ is pixel location in the vertical direction. The cloud masking scheme set SSC values to equal nota-number if a cloud was detected, and thus excluded cloud influenced reflectance values from the statistics.

We then used the 13 year mean SSC map as a spatial template to mimic seasonal SSC fluctuations. For each scene in the season, the 13 year mean SSC map was multiplied by a sinusoidal factor (the scene intensity, $I_{\mathrm{S}}$ ) that peaked near day 190 of each melt-season simulation (Fig. 5).

$\mathrm{SSC}_{i, j}=\overline{13 \text { year } \mathrm{SSC}_{i, j}} \times I_{\mathrm{s}}$,

where

$I_{\mathrm{s}}=x \times \sin \left(\frac{y}{55}\right)$,

$x$ was a number between two and four randomly generated for each scene, and $y$ began at one and increased by one with each scene used. This range was selected by tuning simulated SSC values to the range found in the observed MODIS data set. As an example, Fig. 5 plots how mean SSC was allowed to vary seasonally during computational experiments. 


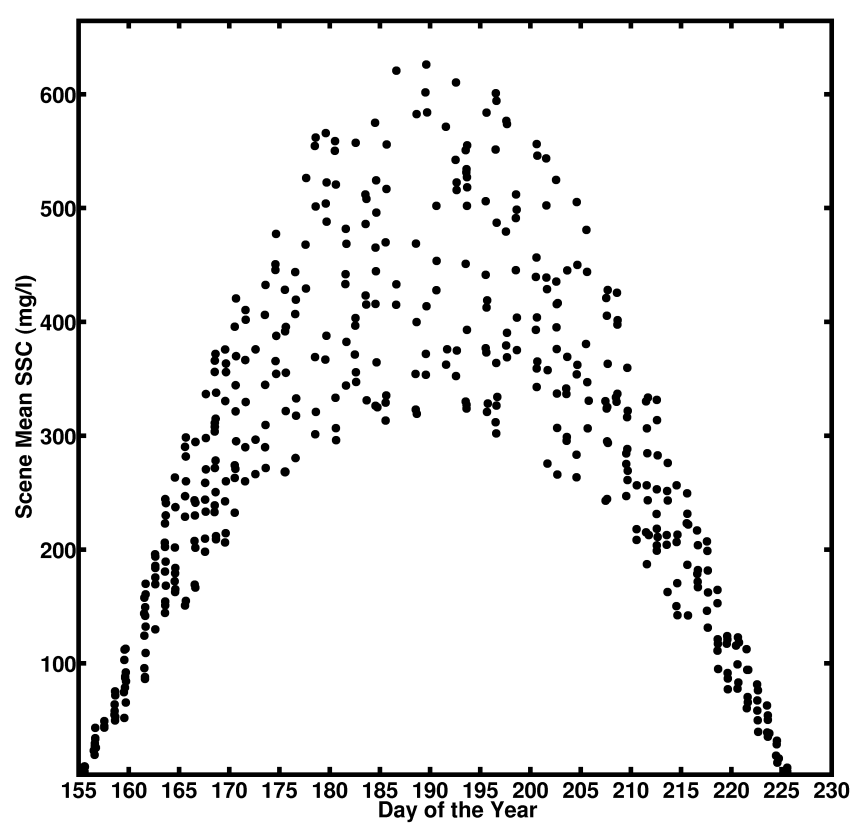

Figure 5. Example of how computational experiment allowed simulated scene suspended sediment concentration (SSC) to vary durring a simulated melt season. For each scene a scene intensity was randomly generated that controls the simulated scene mean SSC (plotted). Three melt seasons are plotted to show a wider range of SSCs allowed.

\subsection{Optimizing the quantification of plume characteristics}

Three metrics were selected to describe plume dynamics and trends over the 13 year record: melt-season mean SSC $\left(\mathrm{SSC}_{\mathrm{msm}}\right)$, percent available fjord pixels in a melt season above $50 \mathrm{mg} \mathrm{L}^{-1}\left(P_{>50}\right)$, and above $250 \mathrm{mg} \mathrm{L}^{-1}\left(P_{>250}\right)$. The melt season was defined as day of year 135 through 295 ( $\sim 15$ May through 22 October). $\mathrm{SSC}_{\mathrm{msm}}$ was selected because cloud masked simulated values were closest to noncloud masked simulated values. $P_{>50}$ was selected because it matches the threshold identified by Arendt et al. (2011) as having a significant impact on copepods and secondary production near Nuuk in Godthåbfjord. $P_{>250}$ was selected because SSC above $250 \mathrm{mg} \mathrm{L}^{-1}$ is a proxy for the plume's zone of flow establishment (Albertson et al., 1950; Syvitski et al., 1988). $P_{>50}$ and $P_{>250}$ were also the most consistent metrics between years in that they were similarly influenced by clouds each year.

Computational experiments explored cloud bias in a number of annual metrics (mean, median, etc.) by imposing the MODIS derived 13 year record of cloud cover on the simulated data set (Fig. 6). In addition, these experiments evaluated how metrics calculating the percent of available fjord pixels in a year observed above a specified SSC threshold (50 or $250 \mathrm{mg} \mathrm{L}^{-1}$ ) performed. These $P_{>t}$ metrics describe the duration and the spatial extent of a river plume for a given

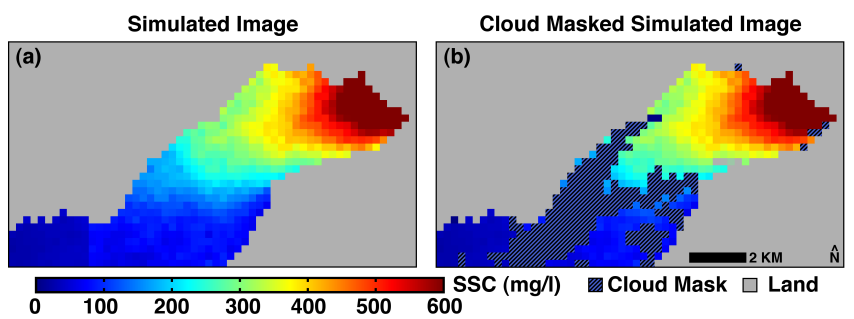

Figure 6. Example of (a) simulated image and (b) cloud masked simulated image for Watson River region of interest (ROI).

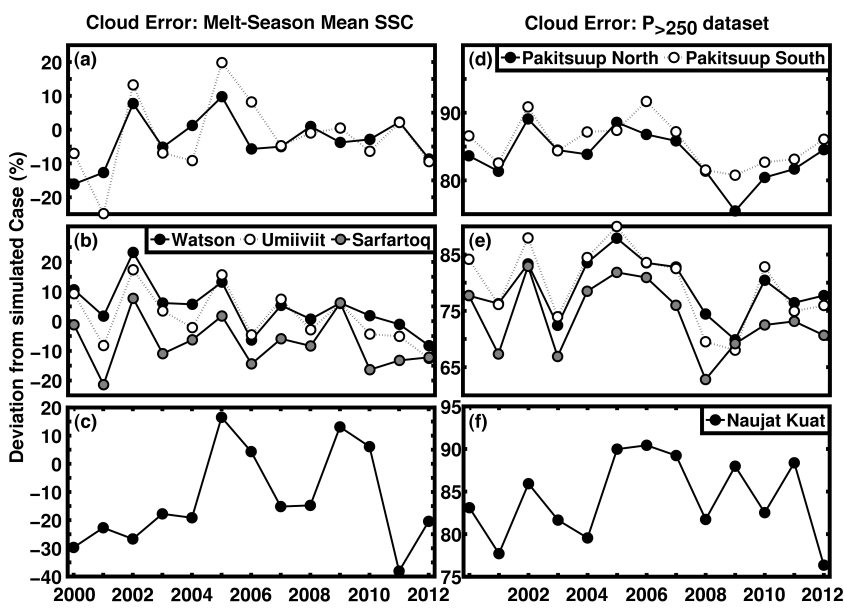

Figure 7. Percent deviation of annual plume metrics from simulated data set was used to constrain error budget. $P_{>50}$ values (not plotted) are similar to $P_{>250}$ values.

region of interest (ROI). They were calculated with two steps. First, for each scene a threshold mask (STM) was created, where all pixels in a ROI greater than the given SSC threshold $t$ were assigned a value of one and all others a value of zero. Second, STM values were summed for an entire melt season and corrected for pixels classified as fjord $\left(F_{\mathrm{p}}\right)$ and the total number of scenes in a year $(S)$ with Eq. (10):

$P_{>t}=\frac{\sum_{\text {day }=135}^{295} \sum_{i} \sum_{j} \mathrm{STM}_{i, j}}{F_{\mathrm{p}} \times S}$.

Variable plume area and fjord shape caused each ROI to vary in size and fjord area. The Pakitsuup north ROI contained a fjord area of $4.4 \mathrm{~km}^{2}$ and Pakitsuup south $4.3 \mathrm{~km}^{2}$. Watson, Umiiviit, and Sarfartoq ROIs contained 41.4, 42.8, and $65.1 \mathrm{~km}^{2}$ of fjord area, respectively. The Naujat Kuat ROI contained a fjord area of $13.0 \mathrm{~km}^{2}$. Tables 3 through 5 report ROI metrics normalized by each ROI 13 year mean to account for this variability.

As Fig. 7 illustrates, $\mathrm{SSC}_{\mathrm{msm}}$ deviated the least from the simulated data set. At most, it underestimated simulated values by $16 \%$ and overestimated by $38 \%$. On average it underestimated by $16 \%$ and overestimated by $12 \%$. The 
maximum range of percent errors found for $\mathrm{SSC}_{\mathrm{msm}}$ was $54 \%$ (Naujat Kuat), with a mean of $36 \%$.

$P_{>50}$ estimates were between 67 and $91 \%$ below simulated values. The maximum range in the deviation from the simulated using $P_{>50}$ for a plume was $22 \%$ (Umiiviit), with an average range of $15 \%$. As Fig. 10d-f show, $P_{>250}$ estimates were similar, between 63 and $92 \%$ below simulated values. The maximum range in the deviation from the simulated was $20 \%$ (Sarfartoq), with an average range of $16 \%$. Cloud obscuration prevents $P_{>t}$ metrics from correctly calculating the true number of times fjord pixels exceed a given value. Thus, absolute values reported may not be reliable. However, we argue this bias did not compromise the usefulness of the metric to detect trends.

We assigned error bars that symmetrically divided the mean range of variability found $\left(\mathrm{SSC}_{\mathrm{msm}} \pm 18 \%\right.$, $P_{>50} \pm 7.5 \%, P_{>250} \pm 8 \%$ ). The large bias in $P_{>t}$ values should also be remembered when interpreting results. We then added error associated with the SSC retrieval to bring overall error assigned to melt-season metrics to $\pm 19 \%$ for $\mathrm{SSC}_{\mathrm{msm}}$ and $\pm 10 \%$ for $P_{>t}$ metrics.

\subsection{RACMO2 runoff data}

To extend our analysis beyond the in situ record, we used yearly catchment scale RACMO2 modeled ice sheet runoff volume (Bamber et al., 2012, hereafter referred to as RACMO2 runoff) as a substitute for observed discharge. Catchments geographically match those in Fig. 3, though differences in area exist due to RACMO2's $5 \mathrm{~km}$ grid. For the four year period of overlap, Watson River observed discharge and RACMO2 runoff were positively correlated $\left(r^{2}=0.5\right)$, although RACMO2 runoff overestimates observed discharge values by 23 to $113 \%$ per year $\left(0.79\right.$ to $\left.2.95 \mathrm{~km}^{3}\right)$ perhaps due to underestimation of englacial storage (Overeem et al., 2014). We did not use RACMO2 runoff for either the Sarfartoq catchment or the Umiiviit River. For the former, no geographically appropriate outlet could be identified and for the latter, the misfit between RACMO2 runoff values and in situ field discharge measurements was too great to be reliable.

\section{Results and discussion}

\subsection{Trends in mean suspended sediment concentration}

We hypothesize that increased freshwater discharge due to increased ice sheet melt has elevated the melt-season SSC of Greenlandic fjords. Overall, $\mathrm{SSC}_{\mathrm{msm}}$ increased for five out of six plumes, although this increase is only statistically significant for the Sarfartoq River plume (Fig. 8). The Pakitsuup south river decreased a statistically insignificant $0.6 \pm 3.9 \mathrm{mg} \mathrm{L}^{-1} \mathrm{yr}^{-1}$. The Sarfartoq River plume $\mathrm{SSC}_{\mathrm{msm}}$ increased $2.1 \pm 1.8 \mathrm{mg} \mathrm{L}^{-1} \mathrm{yr}^{-1}$ ( $p=0.013$ ). We offer two plausible explanations for why this river's trend is statistically significant. First, the Sarfartoq ice sheet catchment may

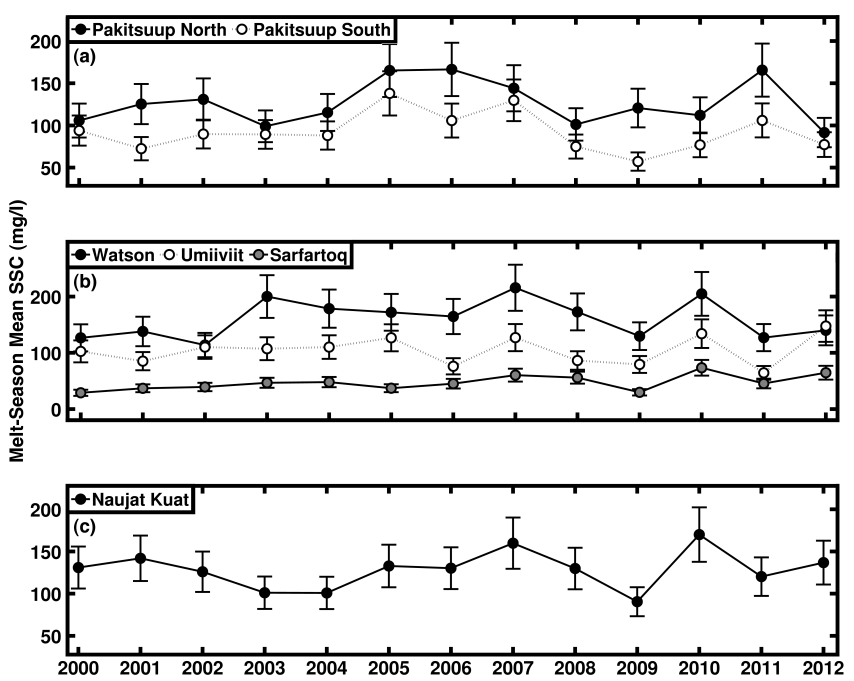

Figure 8. Melt-season mean suspended sediment concentration ( $\mathrm{SSC}_{\mathrm{msm}}$ ) for yearly melt season with error bars for (a) Pakitsuup, (b) Kangerlussuaq, and (c) Ameralik fjord plume(s).

be most sensitive to atmospheric warming because it has the largest below ELA catchment area studied $\left(3291 \mathrm{~km}^{2}, 61 \%\right.$ of its total catchment), and hence large volumes of meltwater production are likely to occur, and are more likely to exit the catchment area, rather than refreeze in the firn (Harper et al., 2012). Second, the Sarfartoq watershed contains two long lakes, Tasersiaq and Tasersiaq Qalia, that may influence plume SSC. Tasersiaq's length $(\sim 71 \mathrm{~km})$ suggests it has a high sediment trapping efficiency for all but the finest particles (Brune, 1953) and that sediment particles that do pass through the lake have a longer transit time than particles that are only transported in rivers. These two characteristics may dampen the magnitude of SSC variability from year to year.

High interannual variability in this natural system, coupled with a relatively short study period, impede the detection of statistically significant trends in other plumes. Further, GrIS mass balance estimates (Shepherd et al., 2012; van den Broeke et al., 2009; Rignot et al., 2008) have shown acceleration in GrIS mass loss beginning in the 1990s. Consequently, the MODIS imagery record only captures the latter half of the response to recent mass balance changes.

\subsection{Trends in plume area metrics}

SSC $P_{>t}$ metrics showed that both areas potentially detrimental to fjord biological productivity $\left(P_{>50}\right)$ and the core of plumes $\left(P_{>250}\right)$ have grown larger and/or more persistent. $P_{>50}$ and $P_{>250}$ significantly increased for all river plumes except for the Pakitsuup south river (Figs. 9 and 10, respectively). Within a given plume ROI, $P_{>50}$ increased between 0.08 and $0.25 \% \mathrm{yr}^{-1}$ when normalized by its 13 year mean and $P_{>250}$ increased between 0.05 and $0.08 \% \mathrm{yr}^{-1}$ when normalized by its 13 year mean. Expressed as the sum of 

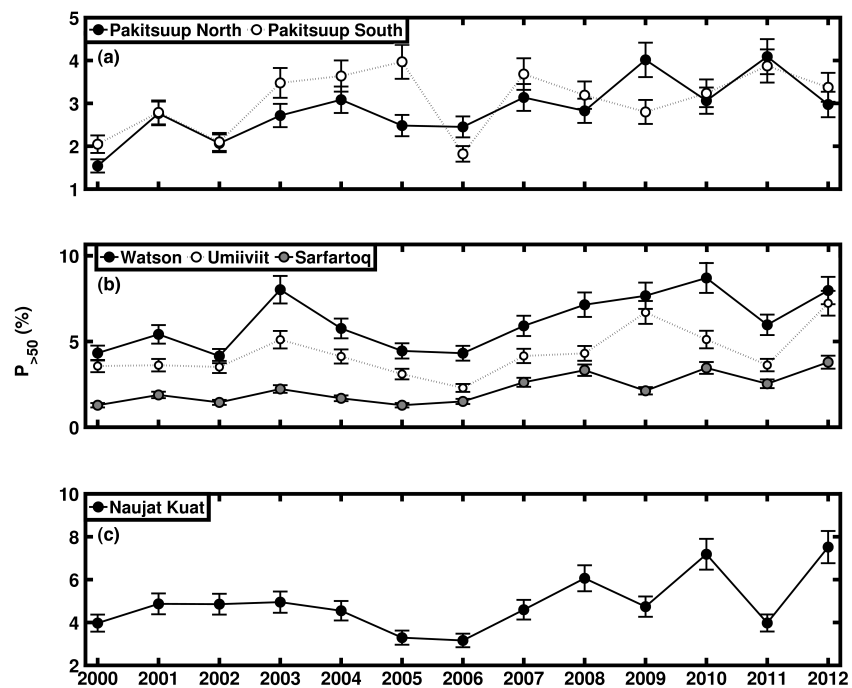

Figure 9. $P_{>50}$ for yearly melt season with error bars for (a) Pakitsuup, (b) Kangerlussuaq, and (c) Ameralik fjord plume(s).

the area of pixels exceeding these thresholds for all images in a melt-season (where 1 pixel $\left.=0.0625 \mathrm{~km}^{2}\right) P_{>50}$ zones increased between 1.4 and $43.2 \mathrm{~km}^{2} \mathrm{yr}^{-1} . P_{>250}$ zones increased between 0.9 and $15.5 \mathrm{~km}^{2} \mathrm{yr}^{-1}$.

$P_{>50}$ trends are significant at the $90 \%$ confidence interval for the Umiiviit $(p=0.061)$ and Naujat Kuat $(p=$ $0.095)$ plumes, the $95 \%$ confidence interval for the Watson plume $(p=0.026)$, and $99 \%$ interval for the Pakitsuup north $(p=0.006)$ and the Sarfartoq plumes $(p=0.002)$. For $P_{>250}$, trends are within the $90 \%$ confidence interval for the Watson $(p=0.087)$, Umiiviit $(p=0.089)$, and Naujat Kuat $(p=0.099)$ plumes, and $99 \%$ interval for the Pakitsuup north $(p=0.010)$ and the Sarfartoq plume $(p=0.006)$.

\subsection{Comparison of fjord SSC to river discharge and ice sheet runoff}

Implicit to our initial hypothesis was that plume SSC and river discharge would be positively correlated, as river SSC and discharge often are. However, at the individual plume level, we find plume $\mathrm{SSC}_{\mathrm{msm}}$ does not directly correlate to the yearly volume of river discharge to the ocean. Total annual river discharge did not closely correspond to $\mathrm{SSC}_{\mathrm{msm}}$ using the Watson gauge data (Hasholt et al., 2013). For example, moderate yearly discharge $\left(3.5_{-0.52}^{+1.68} \mathrm{~km}^{3} \mathrm{yr}^{-1}\right)$ in 2007 corresponded with the highest $\mathrm{SSC}_{\mathrm{msm}}$ recorded $\left(216 \pm 41 \mathrm{mg} \mathrm{L}^{-1}\right)$, while in 2011 a comparable discharge $\left(3.9_{-0.56}^{+1.76} \mathrm{~km}^{3} \mathrm{yr}^{-1}\right)$ produced one of the lowest $\mathrm{SSC}_{\mathrm{msm}}$ values $\left(127 \pm 24 \mathrm{mg} \mathrm{L}^{-1}\right)$. The poor correlation between these variables also exists when RACMO2 annual runoff totals were used to extend the analysis in both time and to additional rivers. Of note, the Naujat Kuat plume $\mathrm{SSC}_{\mathrm{msm}}$ was negatively correlated to RACMO2 runoff $\left(r^{2}=-0.6, p=\right.$ $0.05)$.
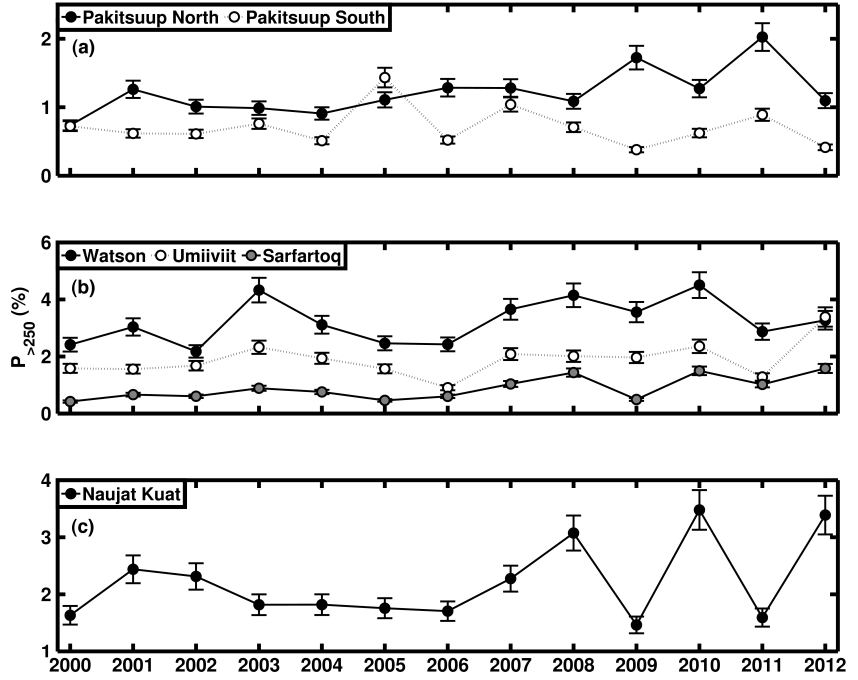

Figure 10. $P_{>250}$ for yearly melt season with error bars for (a) Pakitsuup, (b) Kangerlussuaq, and (c) Ameralik fjord plume(s).

However, when data from multiple river plumes were aggregated, we found larger discharge catchments predicted by the RACMO2 model tended to have higher $\mathrm{SSC}_{\mathrm{msm}}$ values (Fig. 11; $r^{2}=0.64, p<0.001, n=44$ ). This result agrees with Chu et al. (2012) who found melt (as determined from a positive degree day model) was correlated to fjord SSC for large, spatially aggregated $100 \mathrm{~km} \times 100 \mathrm{~km}$ grid cells.

\subsection{Trends between rivers}

During a given year, SSC exhibits a complex spatial relationship between the individual fjord sites. At times, meltseason metrics were similar between individual river plumes (Tables 3 through 5). For example, all river plumes in 2009 displayed $\mathrm{SSC}_{\mathrm{msm}}$ at or below 2000-2012 mean conditions, while during the warm 2010 year all plumes displayed $\mathrm{SSC}_{\mathrm{msm}}$ at or above 2000-2012 mean conditions. However, just as commonly, plume conditions exhibited limited spatial coherence (Figs. 12 and 13). All fjords studied with multiple rivers displayed complex SSC responses in certain years, even for plumes with nearby catchments that presumably experienced similar surface melt conditions. During the extreme melt year of 2012 (Nghiem et al., 2012; McGrath et al., 2013), the Watson River plume $\mathbf{S S C}_{\mathrm{msm}}$ was at or below its 2000 to 2012 mean, while the Umiiviit River plume, with a catchment directly south of the Watson's, experienced a $\mathrm{SSC}_{\mathrm{msm}} 43 \pm 17 \%$ higher than its 13 year mean. This asynchronicity is especially notable as the rivers discharge into the same fjord, and thus background oceanographic conditions are very similar. Differences in SSC for the core of the plume appear to drive this asynchronicity. Both the Watson and Umiiviit have $P_{>50}$ metrics elevated above there 13 year mean, but Watson's $P_{>250}$ metric was close to mean conditions, while the Umiiviit metric was $83 \pm 19 \%$ above. 


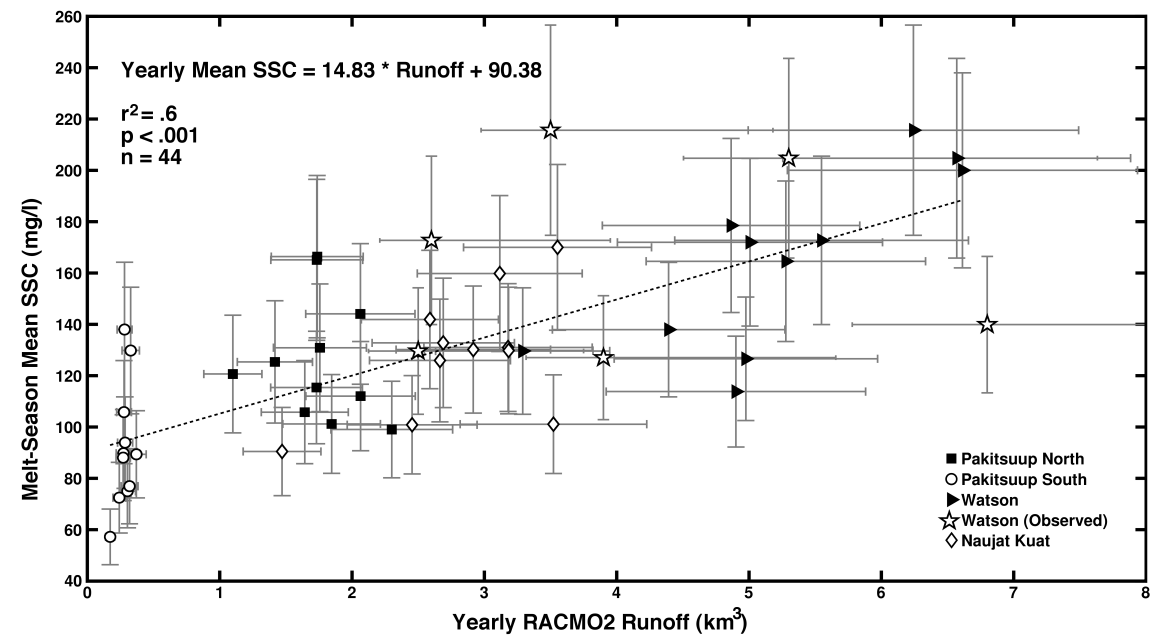

Figure 11. Relationship between yearly RACMO2 modeled runoff and melt-season mean suspended sediment concentration ( $\left.\mathrm{SSC}_{\mathrm{msm}}\right)$ for four river plumes. Watson River observed discharge (Hasholt et al., 2013) and $\mathrm{SSC}_{\mathrm{msm}}$ plotted for comparison, but these data were not included in yearly mean SSC-runoff relationship.

Table 3. Melt-season mean suspended sediment concentration ( $\mathrm{SSC}_{\mathrm{msm}}$ ) percent of 13 year mean. Underlined values are statistically below the mean, bold values statistically above.

\begin{tabular}{|c|c|c|c|c|c|c|}
\hline \multirow[b]{2}{*}{ Year } & \multicolumn{2}{|c|}{ Pakitsuup fjord } & \multicolumn{3}{|c|}{ Kangerlussuaq fjord } & \multirow{2}{*}{$\frac{\text { Ameralik fjord }}{\text { Naujat Kuat }}$} \\
\hline & North & South & Watson & Umiiviit & Sarfartoq & \\
\hline 2000 & 85 & 103 & 80 & 100 & 60 & 102 \\
\hline 2001 & 101 & 79 & $\overline{87}$ & 83 & $\overline{77}$ & 111 \\
\hline 2002 & 106 & $\overline{98}$ & 72 & 107 & $\underline{82}$ & 98 \\
\hline 2003 & $\underline{80}$ & 98 & $1 \overline{26}$ & 104 & 97 & 79 \\
\hline 2004 & 93 & 96 & 112 & 107 & 100 & 79 \\
\hline 2005 & 133 & 151 & 108 & 123 & 77 & 104 \\
\hline 2006 & 134 & 116 & 104 & 74 & 94 & 102 \\
\hline 2007 & 116 & 142 & 136 & 123 & 125 & 125 \\
\hline 2008 & 82 & 82 & 109 & 84 & 116 & 101 \\
\hline 2009 & 97 & 63 & 82 & 77 & 62 & 71 \\
\hline 2010 & 90 & 84 & 129 & 130 & 153 & 133 \\
\hline 2011 & 134 & 116 & $\underline{80}$ & $\underline{63}$ & 94 & 94 \\
\hline 2012 & $\underline{74}$ & 85 & 88 & $1 \overline{43}$ & 134 & 107 \\
\hline
\end{tabular}

Figure $13 d$ shows that the distal plume was above mean values, while pixels near the river mouth were below mean values.

River plumes displayed asynchronicity in other years. During another reportedly high melt year of 2002 (Hanna et al., 2008), the Umiiviit River plume $\mathrm{SSC}_{\mathrm{msm}}$ was close to its 13 year mean SSC, while the Watson River plume $\mathrm{SSC}_{\mathrm{msm}}$ was $28 \pm 14 \%$ below its 13 year mean SSC. In 2005, the Umiiviit River plume $\mathrm{SSC}_{\mathrm{msm}}$ was at or above its 13 year mean SSC, while the Sarfartoq River plume $\mathrm{SSC}_{\mathrm{msm}}$, with a catchment abutting Umiiviit's GrIS catchment, was $23 \pm 15 \%$ below its 13 year mean SSC.
Observed asynchronicity is indicative of the complex sediment dynamics expected in systems controlled by glaciers. Collins (1990) hypothesized that variability in sub-glacial hydrologic networks drove variability in SSC emerging from glaciers. Stott and Grove (2001) recorded transient flushes of increased SSC without increases in discharge for a glaciated (non-GrIS) catchment in Greenland. As mentioned in Sect. 1, river sediment dynamics often show a relationship between discharge and SSC. However, the variable response found may indicate in certain years that ice sheet sediment dynamics, not river sediment dynamics are the dominant control on suspended sediment delivery to the coastal ocean. 
Table 4. Percent available fjord pixels in a melt season above $50 \mathrm{mg} \mathrm{L}^{-1}\left(P_{>50}\right)$ as a percent of statistics' 13 year mean. Underlined values are statistically below the mean, bold values statistically above.

\begin{tabular}{|c|c|c|c|c|c|c|}
\hline \multirow[b]{2}{*}{ Year } & \multicolumn{2}{|c|}{ Pakitsuup fjord } & \multicolumn{3}{|c|}{ Kangerlussuaq fjord } & \multirow{2}{*}{$\begin{array}{r}\text { Ameralik fjord } \\
\text { Naujat Kuat }\end{array}$} \\
\hline & North & South & Watson & Umiiviit & Sarfartoq & \\
\hline 2000 & 46 & $\underline{57}$ & $\underline{60}$ & $\underline{70}$ & 48 & 68 \\
\hline 2001 & 83 & $\overline{78}$ & $\overline{77}$ & 73 & $\overline{73}$ & 87 \\
\hline 2002 & $\underline{72}$ & $\underline{69}$ & $\underline{68}$ & $\underline{82}$ & $\underline{65}$ & 102 \\
\hline 2003 & $\overline{97}$ & $1 \overline{115}$ & $\mathbf{1 3 2}$ & $\mathbf{1 1 9}$ & 100 & 103 \\
\hline 2004 & 112 & 121 & 98 & 99 & 78 & 96 \\
\hline 2005 & $\underline{88}$ & 131 & $7 \underline{75}$ & 74 & $\underline{58}$ & $\underline{70}$ \\
\hline 2006 & $\underline{87}$ & $\underline{60}$ & $\underline{57}$ & 43 & $\underline{54}$ & 64 \\
\hline 2007 & 112 & 122 & 100 & 100 & 122 & $\overline{95}$ \\
\hline 2008 & 102 & 107 & 119 & 102 & 151 & 129 \\
\hline 2009 & 143 & 93 & 129 & 159 & 97 & 100 \\
\hline 2010 & 109 & 107 & 148 & 122 & 160 & 152 \\
\hline 2011 & 146 & 129 & 103 & $\underline{88}$ & 119 & $\underline{84}$ \\
\hline 2012 & 104 & 110 & 134 & 171 & 173 & 151 \\
\hline
\end{tabular}

Table 5. Percent available fjord pixels in a melt season above $250 \mathrm{mg} \mathrm{L}^{-1}\left(P_{>250}\right)$ as a percent of statistics' 13 year mean. Underlined values are statistically below the mean, bold values statistically above.

\begin{tabular}{|c|c|c|c|c|c|c|}
\hline \multirow[b]{2}{*}{ Year } & \multicolumn{2}{|c|}{ Pakitsuup fjord } & \multicolumn{3}{|c|}{ Kangerlussuaq fjord } & \multirow{2}{*}{$\begin{array}{r}\text { Ameralik fjord } \\
\text { Naujat Kuat }\end{array}$} \\
\hline & North & South & Watson & Umiiviit & Sarfartoq & \\
\hline 2000 & $\underline{52}$ & $\underline{87}$ & $\underline{64}$ & $\underline{71}$ & $\underline{40}$ & $\underline{62}$ \\
\hline 2001 & $\underline{89}$ & $\underline{75}$ & $\underline{83}$ & $\underline{72}$ & $\underline{65}$ & 97 \\
\hline 2002 & $\underline{83}$ & $\underline{88}$ & $\underline{68}$ & $\underline{89}$ & $\underline{69}$ & 108 \\
\hline 2003 & $\underline{83}$ & 110 & 136 & $1 \overline{24}$ & 101 & $\underline{84}$ \\
\hline 2004 & $\overline{78}$ & $\underline{74}$ & 101 & 106 & $\underline{089}$ & $\underline{85}$ \\
\hline 2005 & 93 & 206 & $\underline{79}$ & $\underline{85}$ & $\underline{53}$ & $\underline{82}$ \\
\hline 2006 & 108 & $7 \underline{75}$ & $\underline{61}$ & $\underline{39}$ & $\underline{55}$ & $\underline{77}$ \\
\hline 2007 & 108 & 150 & 118 & 115 & 122 & 104 \\
\hline 2008 & 92 & 103 & 132 & 109 & 166 & 145 \\
\hline 2009 & 145 & $\underline{55}$ & 114 & 107 & 57 & 69 \\
\hline 2010 & 107 & $\underline{90}$ & 146 & 129 & 176 & 163 \\
\hline 2011 & 171 & 129 & 94 & $\underline{72}$ & 122 & $\underline{74}$ \\
\hline 2012 & 91 & $\underline{59}$ & 104 & 183 & 184 & 151 \\
\hline
\end{tabular}

Fjord-oceanographic processes, such as the strength of estuarine circulation, may influence plume dynamics. However, data limitations and lack of long-term fjord monitoring restrict quantitative characterization of these processes. The plume SSC observed is consistent with river SSC variability seen in Landsat imagery (Hudson et al., 2014a). Thus, we argue that glacial and river processes dominate the observed variability.

\section{Conclusions}

We developed a retrieval algorithm capable of using MODIS reflectance to measure fjord SSC around Greenland. The SSC retrieval algorithm utilized the largest, most geographically widespread fjord SSC data set for Greenland. Data were collected over four melt seasons between 2008 and 2012, three melt months, and four fjords with highly variable oceanographic conditions. Most of the geologic terrain eroded by the GrIS that drain into study fjords is similar, consisting of Archean and Paleoproterozoic age gneiss (Escher and Pulvertaft, 1995) and the geologic terrain in southwest Greenland sourcing river plumes is generally similar. As a result we argue that the retrieval algorithm is applicable to a larger area than just the study fjords.

The retrieval utilized both the red-visible (band one, 620 to $670 \mathrm{~nm}$ ) and near-infrared (band two, 841 to $876 \mathrm{~nm}$ ) $250 \mathrm{~m}$ resolution bands of MODIS. The combination of these bands provided accurate retrievals of SSC concentrations much higher than previous single band retrieval algorithms (e.g., Chu et al., 2009). In addition, a rigorous cloud detection 

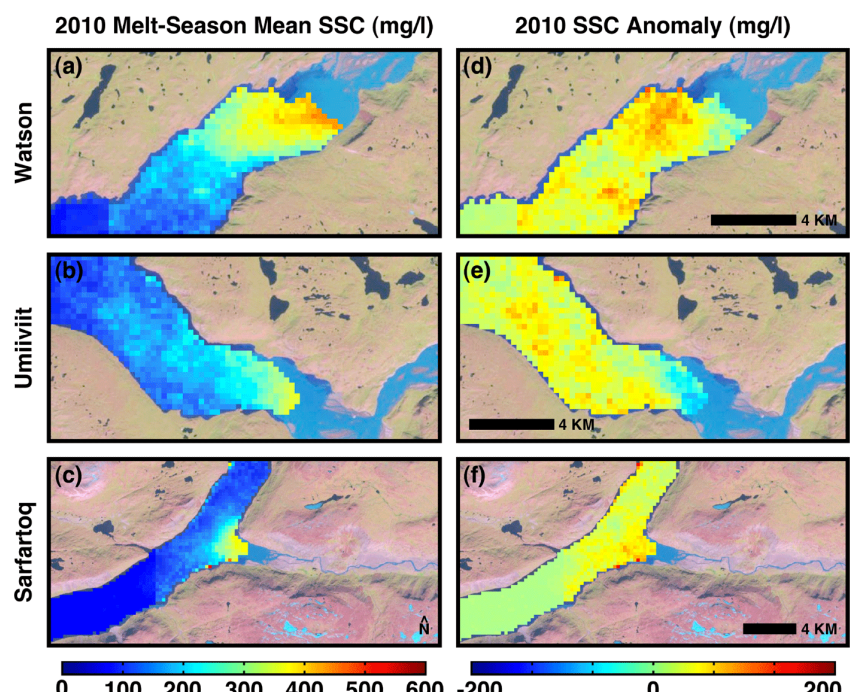

Figure 12. Maps of 2010 melt-season mean suspended sediment concentration $\left(\mathrm{SSC}_{\mathrm{msm}}\right)$ and its anomaly from its 13 year mean for plume regions of interest. Landsat 7 false color image from 7 July 2001 underlaid for reference.

scheme was developed for differentiating between turbid water and clouds, which minimizes cloud contamination of the retrieval (Appendix A).

An analysis using this retrieval on 13 years of MODIS imagery showed that $\mathrm{SSC}_{\mathrm{msm}}$ has increased for most plumes. Intra-annual and regional variability is large in Arctic regions though, and this makes it difficult to arrive at statistically significant trends over the 13 year record.

Metrics describing the duration and the spatial extent of river plumes responded more pronouncedly to the increased melt of the GrIS. High-concentration plumes that can impair biological productivity expanded in most fjords and one-third of the river plumes expand its high-concentration core zone in time and extent ( $95 \%$ confidence interval).

While the relationship between the $\mathrm{SSC}_{\mathrm{msm}}$ of a river plume and its volume of water discharged is not correlated interannually, there appears to be a relationship between yearly modeled runoff totals and $\mathrm{SSC}_{\mathrm{msm}}$ when rivers are studied as a regional aggregate. We found that larger rivers tended to have higher plume $\mathrm{SSC}_{\mathrm{msm}}$.
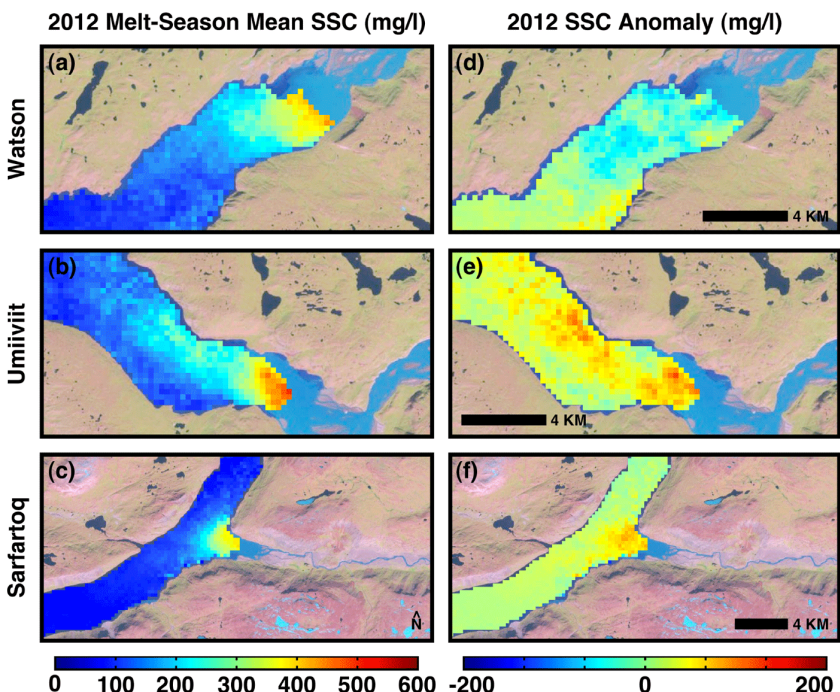

Figure 13. Maps of 2012 melt-season mean suspended sediment concentration $\left(\mathrm{SSC}_{\mathrm{msm}}\right)$ and its anomaly from its 2000 through 2012 mean for plume regions of interest. Landsat 7 false color image from 7 July 2001 underlaid for reference.

The behavior of fjord sediment plumes over the MODIS record was complex, and variable from catchment to catchment, even in catchments that are proximal to one another. This high spatial and temporal variability suggests that approaches that treat the GrIS as a whole, or even composed of distinct regions, may not be applicable to the study of sediment dynamics. Numerous and frequently non-linear processes operating in the glacio-fluvial-fjord systems preclude a simple relationship between these parameters. Because of this complexity, orbital remote sensing of sediment dynamics offers a unique and important perspective for observing change in the GrIS system and should be continued. 


\section{Appendix A: MODIS batch processing}

Due to the high volume of MODIS swath imagery, scripts written in the Python 2.7 programming language requested, downloaded, and processed required MODIS products. Spatial subsets of MODIS MOD02, MOD03, and MOD35_L2 data for all three study fjords were requested and downloaded using the MODAPS Web Services Application Programming Interface (http://ladsweb.nascom.nasa.gov/data/api.html).

Multiple scientific data sets were processed to accurately extract fjord SSC. The following steps were taken to process reflectance imagery. Only scenes imaged between 13:00 and 17:00 UTC were processed to control for solar illumination variability.

1. MOD02 band one and two scaled integers were converted into $R_{\mathrm{rs}}$ using the procedure outlined in the MODIS Level 1B Product User's Guide (Toller et al., 2009).

2. $R_{\mathrm{rs}}$ values were corrected for atmospheric effects using dark object subtraction by finding the lowest reflectance value in the scene and subtracting all scene reflectance values by it.

3. $R_{\mathrm{rs}}$ were corrected with the MOD03 solar zenith angle product.

4. Pixels that had a solar zenith angle greater than 60 degrees were masked out.

5. A land mask derived from the DNSC coastline and Landsat 7 Global Land Survey data (http://gls.umd. edu/) was used to mask out land pixels, and pixels that had a mixture of land and water in them to avoid land contamination effects.

6. An additional mask omitted all pixels wherein band two reflectance was greater than 0.17 for zones near-reach river mouth, and 0.13 at the rest of fjord to minimize cloud noise.
For Ameralik fjord, all scenes between day 135 and 295 were considered. For Kangerlussuaq and Pakitsuup fjords, scenes were considered as soon as ice-free conditions were observed for each year. For Kangerlussuaq fjord this ranged between day of the year 143 and 160. For Pakitsuup fjord it ranged between days of the year 144 and 166 .

The MOD35_L2 cloud mask uses many of the 36 MODIS bands to detect and mask clouds. However, it incorrectly masks the highly turbid core of river plumes as clouds on the basis that water in the near infrared should have very low reflectance. This assumption does not hold in these highly turbid regions. For turbid water, the MOD35_L2 visible reflectance test (bit 20) and reflectance ratio test (bit 21) incorrectly classify turbid plumes as cloud (Ackerman et al., 2006). Instead, a custom cloud mask was built from MOD35_L2 data using the following clouds tests. The following tests were applied (for more detail on tests see Ackerman et al., 2006)

1. Non-cloud obstruction (i.e., smoke from fires, dust storms) (bit 8).

2. Thin cirrus test using $1380 \mathrm{~nm}$ light (bit 9).

3. Shadow test for high confidence clear pixels (bit 10).

4. Thin cirrus test independent of bit 9 (bit 11).

5. High cloud test using $6700 \mathrm{~nm}$ light (bit 15).

6. IR temperature difference test using 8600,11000 , and $12000 \mathrm{~nm}$ light (bit 18).

7. Low level water clouds test using difference between $11000 \mathrm{~nm}$ and $3900 \mathrm{~nm}$ light (bit 19).

8. Test described in Hudson et al. (2014b).

If any test was failed, the pixel was excluded from analysis. All data sets were then gridded to a common $250 \mathrm{~m}$ by $250 \mathrm{~m}$ UTM grid using MOD03 and MOD35_L2 geolocation data. 
Acknowledgements. This project was funded through NSF-OPP Award 0909349. We thank CH2MHill - Polar Field Services for logistic support, Michael Rosing, Jorgen Mortensen, Karsten Lings, and Silver Scivoli for help with oceanographic surveys, Aaron Zettler-Mann, Ursula Rick, Katy Barnhart, and Leif Anderson helped with field and oceanographic work. We thank Alberto Reyes (Queen's University Belfast) for collection of samples used from Orpigsoq fjord, Wendy Freeman for help in the processing of sediment samples, and Jonathan Bamber (University of Bristol), Janneke Ettema (University of Twente), and Michiel van den Broeke (Utrecht University) for sharing RACMO2 data.

Edited by: M. van den Broeke

\section{References}

Ackerman, S., Strabala, K., Menzel, P., Frey, R., Moeller, C., Gumley, L., Baum, B., Wetzel Seeman, S., and Zhang, H.: Discrimiating clear-sky from clouds with MODIS, Algorithm Theoretical Basis Document (MOD35), Version 5.0, NASA, MODIS Cloud Mask Team, Madison, WI, 125 pp., 2006.

Albertson, M. L., Dai, Y. B., Jensen, R. A., and Rouse, H.: Diffusion of submerged jets, T. Am. Soc. Civ. Eng., 115, 639-664, 1950.

Alley, R. B., Cuffey, K. M., Evenson, E. B., Strasser, J. C., Lawson, D. E. and Larson, G.: How glaciers entrain and transport basal sediment: Physical constraints, Quaternay Sci. Rev., 16, 10171038, 1997.

Anderson, R. S. and Anderson, S. P.: Geomorphology: The Mechanics and Chemistry of Landscapes, Cambridge University Press, Cambridge, 2010.

Arendt, K. E., Dutz, J., Jonasdottir, S. H., Jung-Madsen, S., Mortensen, J., Moller, E. F., and Nielsen, T. G.: Effects of suspended sediments on copepods feeding in a glacial influenced sub-Arctic fjord, J. Plankton Res., 33, 1526-1537, doi:10.1093/plankt/fbr054, 2011.

Bamber, J. L., Layberry, R. L., and Gogineni, S. P.: New ice thickness and bed data set for the Greenland Ice sheet 1. Measurement, data reduction, and errors, J. Geophys. Res., 106, 33773-33780, doi:10.1029/2001JD900054, 2001.

Bamber, J. L., van den Broeke, M., Ettema, J., Lenaerts, J., and Rignot, E.: Recent large increases in freshwater fluxes from Greenland into the North Atlantic, Geophys. Res. Lett., 39, L19501, doi:10.1029/2012GL052552, 2012.

Bamber, J. L., Griggs, J. A., Hurkmans, R. T. W. L., Dowdeswell, J. A., Gogineni, S. P., Howat, I., Mouginot, J., Paden, J., Palmer, S., Rignot, E., and Steinhage, D.: A new bed elevation dataset for Greenland, The Cryosphere, 7, 499-510, doi:10.5194/tc-7499-2013, 2013.

Barbieri, R., Montgomery, H., Qiu, S., Barnes, B., Knowles, D., Che, N., and Goldberg, I. L.: Draft of the MODIS Level 1B Algorithm Theoretical Basis Document, Version 2.0, NASA, Greenbelt, MD, 68 pp., 1997.

Brune, G. M.: Trap efficiency of reservoirs, T. Am. Geophys. Un., 34, 407-418, 1953.

Chu, V. W., Smith, L. C., Rennermalm, A. K., Forster, R. R., Box, J. E., and Reeh, N.: Sediment plume response to surface melting and supraglacial lake drainages on the Greenland ice sheet, J. Glaciol., 55, 1072-1082, doi:10.3189/002214309790794904, 2009.
Chu, V. W., Smith, L. C., Rennermalm, A. K., Forster, R. R., and Box, J. E.: Hydrologic controls on coastal suspended sediment plumes around the Greenland Ice Sheet, The Cryosphere, 6, 119, doi:10.5194/tc-6-1-2012, 2012.

Church, M.: Baffin Island Sandurs: A Study of Arctic Fluvial Processes, Geol. Surv. of Can., Ottawa, Ont., Bulletin 216, 208 pp., 1972.

Collins, D. N.: Seasonal and annual variations of suspended sediment transport in meltwaters draining from an Alpine glacier, in: Hydrology in Mountainous Regions I: Hydrological Measurements; the Water Cycle, IAHS Publ. No. 193, 439-446, available at: http://iahs.info/redbooks/a193/iahs_193_0439.pdf, 1990.

Cottier, F. R., Nielsen, F., Skogseth, R., Tverberg, V., Skardhamar, J., and Svendsen, H.: Arctic fjords: a review of the oceanographic environment and dominant physical processes, in: Fjord Systems and Archives, edited by: Howe, J. A., Austin, W. E. N., Forwick, M., and Patzel, M., The Geological Society, London, 380 pp., 2010.

Cowton, T., Nienow, P., Bartholomew, I., Sole, A., and Mair, D.: Rapid erosion beneath the Greenland ice sheet, Geology, 40, 343-346, doi:10.1130/G32687.1, 2012.

Cuffey, K. and Paterson, W. S. B.: The Physics of Glaciers, 4th edn., Elsevier Inc., Burlington, Oxford, 2010.

Cushman-Roisin, B., Asplin, L., and Svendsen, H.: Upwelling in broad fjords, Cont. Shelf Res., 14, 1701-1721, 1994.

Escher, J. C. and Pulvertaft, T. C. R.: Geological map of Greenland, 1: 2500000, Geol. Surv. of Greenland, 1995.

Ettema, J., van den Broeke, M. R., van Meijgaard, E., van de Berg, W. J., Bamber, J. L., Box, J. E., and Bales, R. C.: Higher surface mass balance of the Greenland ice sheet revealed by highresolution climate modeling, Geophys. Res. Lett., 36, L12501, doi:10.1029/2009GL038110, 2009.

Fenn, C. R., Gurnell, A. M., and Beecroft, I. R.: An evaluation of the use of suspended sediment rating curves for the prediction of suspended sediment concentration in a proglacial stream, Geogr. Ann., 67, 71-82, doi:10.2307/520467, 1985.

Goldthwait, R., Mirsky, A., Crowl, G., Koob, D., and Richard, P.: Tasersiaq Area-Sukkertoppen Ice Cap Studies, Report 1701-2, Institute of Polar Studies, The Ohio State University, Columbus, Ohio, 68 pp., available at: https://kb.osu.edu/dspace/handle/ 1811/52119, 1964.

Gregg, W. W. and Casey, N. W.: Sampling biases in MODIS and SeaWiFS ocean chlorophyll data, Remote Sens. Environ., 111, 25-35, doi:10.1016/j.rse.2007.03.008, 2007.

Hanna, E., Huybrechts, P., Steffen, K., Cappelen, J., Huff, R., Shuman, C., Irvine-Fynn, T., Wise, S., and Griffiths, M.: Increased runoff from melt from the Greenland Ice Sheet: a response to global warming, J. Climate, 21, 331-341, doi:10.1175/2007JCLI1964.1, 2008.

Harper, J., Humphrey, N., Pfeffer, W. T., Brown, J., and Fettweis, X.: Greenland ice-sheet contribution to sea-level rise buffered by meltwater storage in firn, Nature, 491, 240-243, doi:10.1038/nature11566, 2012.

Hasholt, B.: Sediment Transport in Greenland, in: Erosion and Sediment Yield: Global and Regional Perspectives, IAHS Publ. no. 236, 105-114, available at: http://www.irtces.org/isi/isi_ document/iahs236/, 1996.

Hasholt, B., Bobrovitskaya, N., Bogen, J., McNamara, J., Mernild, S. H., Milburn, D., and Walling, D. E.: Sediment transport to the 
Arctic Ocean and adjoining cold oceans, Nord. Hydrol., 37, 413432, doi:10.2166/nh.2006.023, 2006.

Hasholt, B., Mikkelsen, A. B., Nielsen, M. H., and Larsen, M. A. D.: Observations of runoff and sediment and dissolved loads from the Greenland Ice Sheet at Kangerlussuaq, West Greenland, 2007 to 2010, Z. Geomorphol., 57, 3-27, doi:10.1127/03728854/2012/S-00121, 2013.

Howat, I. M., Negrete, A., and Smith, B. E.: The Greenland Ice Mapping Project (GIMP) land classification and surface elevation datasets, The Cryosphere Discuss., 8, 453-478, doi:10.5194/tcd-8-453-2014, 2014.

Hudson, B., Overeem, I., and Syvitski, J. P. M., and Mikkelsen, A. B.: The Greenland Ice Sheet's role in setting river and fjord suspended sediment concentration, A test case from two west Greenland rivers. 44th International Arctic Workshop, Program and Abstracts 2014, Institute of Arctic and Alpine Research (INSTAAR), University of Colorado at Boulder, 131 pp., 2014a.

Hudson, B., Overeem, I., and Syvitski, J. P. M.: A new technique to detect turbid water, and mask clouds in coastal, case two waters, in preparation, 2014b.

Inall, M. E. and Gillibrand, P. A.: The Physics of mid-latitude fjords: a review, in: Fjord Systems and Archives, edited by: Howe, J. A., Austin, W. E. N., Forwick, M., and Patzel, M., The Geological Society, London, 380 pp., 2010.

Kirk, J. T. O.: Light and Photosynthesis in Aquatic Ecosystems, 3rd Edn., Cambridge University Press, Cambridge, UK, 649 pp., 2011.

Lewis, S. M. and Smith, L. C.: Hydrologic drainage of the Greenland Ice Sheet, Hydrol. Process., 23, 2004-2011, doi:10.1002/hyp.7343, 2009.

McGrath, D., Steffen, K., Overeem, I., Mernild, S. H., Hasholt, B., and van den Broeke, M.: Sediment plumes as a proxy for local ice-sheet runoff in Kangerlussuaq Fjord, West Greenland, J. Glaciol., 56, 813-821, doi:10.3189/002214310794457227, 2010.

McGrath, D., Colgan, W., Steffen, K., Lauffenburger, P., and Ba$\log$, J.: Assessing the summer water budget of a moulin basin in the Sermeq Avannarleq ablation region, Greenland ice sheet, J. Glaciol., 57, 954-964, doi:10.3189/002214311798043735, 2011.

McGrath, D., Colgan, W., Bayou, N., Muto, A., and Steffen, K.: Recent warming at Summit, Greenland: global context and implications, Geophys. Res. Lett., 40, 1-6, doi:10.1002/grl.50456, 2013.

Mernild, S. H. and Hasholt, B.: Observed runoff, jokulhlaups and suspended sediment load from the Greenland ice sheet at Kangerlussuaq, West Greenland, 2007 and 2008, J. Glaciol., 55, 855858, 2009

Mernild, S. H., Liston, G. E., Steffen, K., and Chylek, P.: Meltwater flux and runoff modeling in the ablation area of Jakobshavn Isbræ, West Greenland, J. Glaciol., 56, 20-32, doi:10.3189/002214310791190794, 2010.

Miller, R. L. and McKee, B. A.: Using MODIS Terra $250 \mathrm{~m}$ imagery to map concentrations of total suspended matter in coastal waters, Remote Sens. Environ., 93, 259-266, doi:10.1016/j.rse.2004.07.012, 2004.

Mobley, C. D.: Estimation of the remote-sensing reflectance from above-surface measurements, Appl. Optics, 38, 7442-7455, 1999.
Morehead, M. D., Syvitski, J. P. M., Hutton, E. W. H., and Peckham, S. D.: Modeling the temporal variability in the flux of sediment from ungauged river basins, Global Planet. Change, 39, 95-110, doi:10.1016/S0921-8181(03)00019-5, 2003.

Mote, T.: Ablation rate estimates over the Greenland Ice Sheet from microwave radiometric data, Prof. Geogr., 52, 322-331, doi:10.1111/0033-0124.00228, 2000.

Nghiem, S. V., Hall, D. K., Mote, T. L., Tedesco, M., Albert, M. R., Keegan, K., Shuman, C. A., Di Girolamo, N. E., and Neumann, G.: The extreme melt across the Greenland ice sheet in 2012, Geophys. Res. Lett., 39, L20502, doi:10.1029/2012GL053611, 2012.

O'Farrell, C. R., Heimsath, A. M., Lawson, D. E., Jorgensen, L. M., Evenson, E. B., Larson, G., and Denner, J.: Quantifying periglacial erosion: insights on a glacial sediment budget, Matanuska Glacier, Alaska, Earth Surf. Proc. Land., 34, 20082022, doi:10.1002/esp.1885, 2009.

Østrem, G.: Sediment transport in glacial meltwater streams, Glaciofluvial Glaciolacustrine Sediment, 23, 101-122, 1975.

Overeem, I., Hudson, B., Welty, E. Mikkelsen, A., Pedersen, D., LeWinter, A., and Hasholt, B.: River Inundation Reveals Ice Sheet Runoff Variations, J. Glaciol., in review, 2014.

Peckham, S. D.: A new method for estimating suspended sediment concentrations and deposition rates from satellite imagery based on the physics of plumes, Comput. Geosci., 34, 11981222, doi:10.1016/j.cageo.2008.02.009, 2008.

Peckham, S. D.: Geomorphometry in RiverTools, Dev. Soil Sci., 33, 411-430, doi:10.1016/S0166-2481(08)00018-4, 2009.

Retamal, L., Bonilla, S., and Vincent, W. F.: Optical gradients and phytoplankton production in the Mackenzie River and the coastal Beaufort Sea, Polar Biol., 31, 363-379, doi:10.1007/s00300007-0365-0, 2008.

Rignot, E., Box, J. E., Burgess, E., and Hanna, E.: Mass balance of the Greenland ice sheet from 1958 to 2007 , Geophys. Res. Lett., 35, L20502, doi:10.1029/2008GL035417, 2008.

Seidenkrantz, M. S., Aagaard-Sorensen, S., Sulsbruck, H., Kuijpers, A., Jensen, K. G., and Kunzendorf, H.: Hydrography and climate of the last 4400 years in a SW Greenland fjord: implications for Labrador Sea palaeoceanography, The Holocene, 17, 387-401, doi:10.1177/0959683607075840, 2007.

Shepherd, A., Ivins, E. R., A, G., Barletta, V. R., Bentley, M. J., Bettadpur, S., Briggs, K. H., Bromwich, D. H., Forsberg, R., Galin, N., Horwath, M., Jacobs, S., Joughin, I. R., King, M. A., Lenaerts, J. T. M., Li, J., Ligtenberg, S. R. M., Luckman, A., Luthcke, S. B., McMillan, M., Meister, R., Milne, G., Mouginot, J., Muir, A., Nicolas, J. P., Paden, J., Payne, A. J., Pritchard, H., Rignot, E., Rott, H., Sorensen, L. S., Scambos, T. A., Scheuchl, B., Schrama, E. J. O., Smith, B., Sundal, A. V., van Angelen, J. H., van de Berg, W. J., van den Broeke, M. R., Vaughan, D. G.,Velicogna, I.,Wahr, J., Whitehouse, P. L., Wingham, D. J., Yi, D., Young, D., and Zwally, H. J.: A reconciled estimate of ice-sheet mass balance, Science, 338, 1183-1189, doi:10.1126/science.1228102, 2012.

Skogseth, R., Sandvik, A., and Asplin, L.: Wind and tidal forcing on the meso-scale circulation in Storfjorden, Svalbard, Cont. Shelf Res., 27, 208-227, doi:10.1016/j.csr.2006.10.001, 2007.

Statham, P. J., Skidmore, M., and Tranter, M.: Inputs of glacially derived dissolved and colloidal iron to the coastal ocean and im- 
plications for primary productivity, Global Biogeochem. Cy., 22, 1-11, doi:10.1029/2007GB003106, 2008.

Stott, T. A. and Grove, J. R.: Short-term discharge and suspended sediment fluctuations in the proglacial Skeldal River, north-east Greenland, Hydrol. Process., 15, 407-423, 2001.

Syvitski, J. P. M.: Modeling the sedimentary fill of basins, in: Geological Survey of Canada, Paper 89-9: Statistical Applications in the Earth Sciences, edited by: Agterberg, F. P. and BonhamCarter, G. F.,Geological Survey of Canada, Ottawa, 505-515, 1990.

Syvitski, J. P. M. and Murray, J.: Particle interaction in fjord suspended sediment, Mar. Geol., 39, 215-242, 1981.

Syvitski, J. P. M., Asprey, K., Clattenburg, D., and Hodge, G. D.: The prodelta environment of a Fjord: suspended particle dynamics, Sedimentology, 32, 83-107, 1985.

Syvitski, J. P. M., Smith, J. N., Calabrese, E. A., and Boudreau, B. P.: Basin Sedimentation and the Growth of Prograding Deltas, J. Geophys. Res., 93, 6895-6908, 1988.

Syvitski, J. P. M., Morehead, M. D., Bahr, D. B., and Mulder, T.: Estimating fluvial sediment transport: the rating parameters, Water Resour. Res., 36, 2747-2760, doi:10.1029/2000WR900133, 2000.
Tedstone, A. J. and Arnold, N. S.: Automated remote sensing of sediment plumes for identification of runoff from the Greenland ice sheet, J. Glaciol., 58, 699-712, doi:10.3189/2012JoG11J204, 2012.

Toller, G. N., Isaacman, A., Kuyper, J., and Geng, X.: MODIS Level 1B Product User's Guide, NASA, Greenbelt, MD, 57 pp., 2009.

van den Broeke, M., Bamber, J. L., Ettema, J., Rignot, E., Schrama, E., van de Berg, W. J., van Meijgaard, E., Velicogna, I., and Wouters, B.: Partitioning Recent Greenland Mass Loss, Science, 326, 984-986, doi:10.1126/science.1178176, 2009.

van de Wal, R. S. W., Boot, W., Smeets, C. J. P. P., Snellen, H., van den Broeke, M. R., and Oerlemans, J.: Twenty-one years of mass balance observations along the K-transect, West Greenland, Earth Syst. Sci. Data, 4, 31-35, doi:10.5194/essd-4-312012, 2012.

Weidick, A. and Citterio, M.: The ice-dammed lake Isvand, West Greenland, has lost its water, J. Glaciol., 57, 186-188, 2011.

Zwally, H. J., Abdalati, W., Herring, T., Larson, K., Saba, J., and Steffen, K.: Surface melt-induced acceleration of Greenland icesheet flow., Science, 297, 218-22, doi:10.1126/science.1072708, 2002. 